2. To: (Receiving Organization)

Distribution

5. Proj./Prog./Dept./Div.:

TWRS/71330/W236A

8. Originator Remarks:

Transmitted for approval and release.
3. From: (Originating Organization) Process Control

6. Cog. Engr.:

D. A. Reynolás
4. Related EDT No.:

$N / A$

7. Purchase Order No.: $N / A$

9. Equip./Component No.: $N / A$

10. System/Bldg./Facility: $N / A$

T1. Receiver Remarks:

12. Major Assm. Dwg. No.: $N / A$

13. Permit/Permit Application No.: $N / A$

14. Required Response Date:

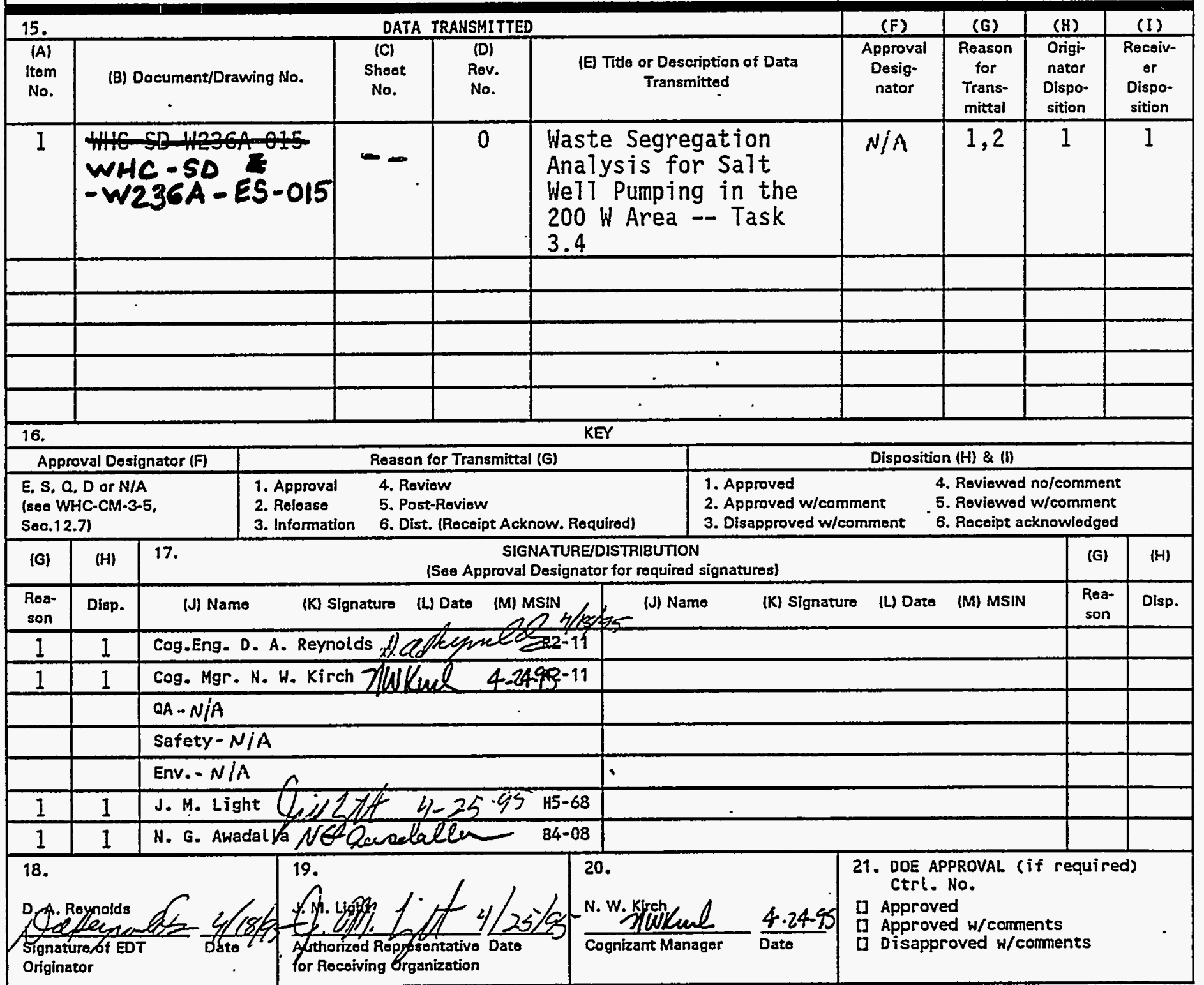




\section{DISCLAIMER}

Portions of this document may be illegible in electronic image products. Images are produced from the best available original document. 


\section{SUPPORTING DOCUMENT}

1. Total Pages 245

\begin{tabular}{|c|c|}
\hline $\begin{array}{l}\text { 2. Title } \\
\text { Waste Segregation Analysis for Salt Well Pumping } \\
\text { in the } 200 \mathrm{~W} \text { Area -- Task } 3.4\end{array}$ & 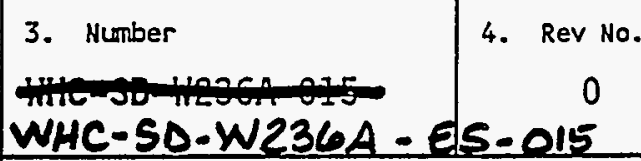 \\
\hline $\begin{array}{l}\text { 5. ' Key Words } \\
\text { Salt Well Pumping, Complexed Waste, 102-SY }\end{array}$ & 6. Author \\
\hline
\end{tabular}

7. Abstract

There is an estimate 7 million liters ( 1.9 million gallons) of potentially complexed waste that need to be pumped from single-shell (SST) tanks in the $200 \mathrm{~W}$ Area. There are three double-she11 (DST) tanks in the $200 \mathrm{~W}$ Area. Tank 241-SY-101 is fuTl and not usable. Tank 241-SY-102 has a transuranic (TRU) sludge in the bottom. Current rules prohibit mixing complexed waste with TRU waste. Tank 241-SY-103 has three major problems. First, 103-SY is on the Flammable Watch 7 ist. Second, adding waste to 103-SY has the potential for an episodic release of hydrogen gas. Third, 103-SY will not hold all of the potentially complexed waste from the single-shell tanks.

This document looks at more details regarding the salt well pumping of the 200 West Area tank farm. Some options are considered but it is beyond the scope of this document to provide an in-depth study necessary to provide a defensibie solution to the complexed waste problem.

\section{DISCLAIMER}

This report was prepared as an account of work sponsored by an agency of the United States Government. Neither the United States Government nor any agency thereof, nor any of their employees, makes any warranty, express or implied, or assumes any legal liability or responsibility for the accuracy, completeness, or usefulness of any information, apparatus, product, or process disclosed, or represents that its use would not infringe privately owned rights. Reference herein to any specific commercial product, process, or service by trade name, trademark, manufacturer, or otherwise does not necessarily constitute or imply its endorsement, recommendation, or favoring by the United States Government or any agency thereof. The views and opinions of authors expressed herein do not necessarily state or reflect those of the United States Government or any agency thereof.

8. RELEASE STAMP

OFFIGIAL REIEASE BY IR-23BA IMT
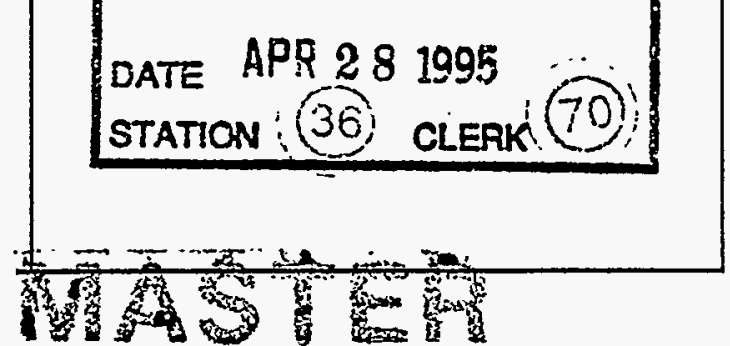


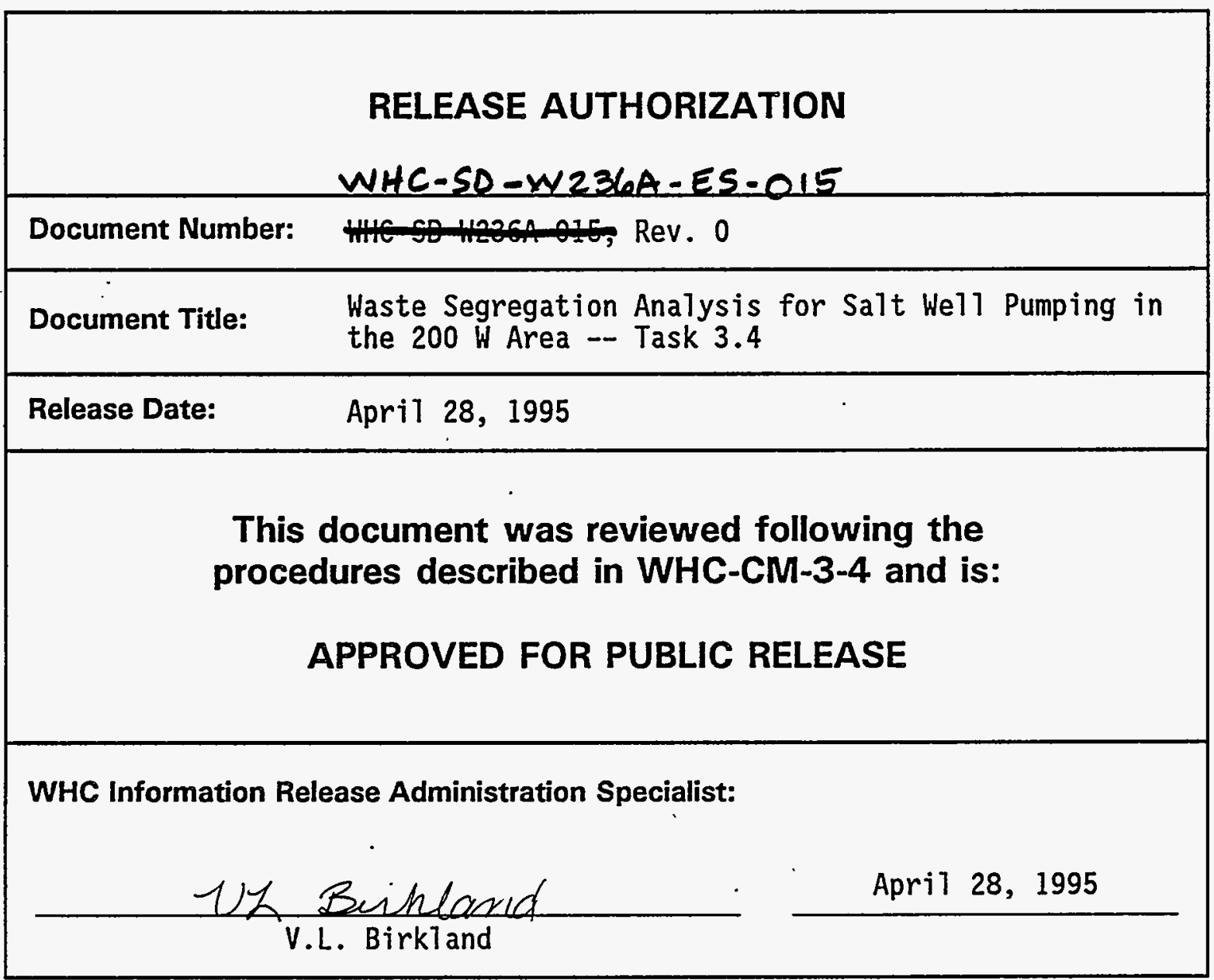

TRADEMARK DISCLAIMER. Reference herein to any specific commercial product, process, or service by trade name, trademark, manufacturer, or otherwise, does not necessarily constitute or imply its endorsement, recormendation, or favoring by the United States Goverment or any agency thereof or its contractors or subcontractors.

This report has been reproduced from the best available copy. Available in paper copy and microfiche. Printed in the United States of America. Available to the U.S. Department of Energy and its contractors from:

U.S. Department of Energy

Office of Scientific and Technical information (OSTI)

P.0. Box 62

Oak Ridge, TN 37831

Telephone: (615) 576-8401

Available to the public from:

U.S. Department of Commerce

National Technical Information Service (NTIS)

5285 Port Royal Road

Springfield, VA 22161

Telephone: (703) $487-4650$ 
WHC-SD-W236A-ES-015

REV. 0

\section{Waste Segragation Analysis for Salt Well Pumping in the 200 West Area \\ Tanks 3.4}

D.A. Reynolds

April, 1995 
WHC-SD-W236A-ES-015

REV. 0

WASTE SEGREGATION ANALYSIS FOR SALT WELL PUMPING IN THE 200 WEST AREA - TASK 3.4

Daniel A. Reynolds

\section{ABSTRACT}

There is an estimated 7 million liters ( 1.9 mil7ion gallons) of potentially complexed waste that need to be pumped from single-shell tanks (SST) in the 200 West Area. This represents up to $40 \%$ of the salt well 7iquor that needs to be pumped in the 200 West Area. There are three double-shell (DST) tanks in the 241-SY tank farm in the 200 West Area. Tank 241-SY-101 is ful1 and not usable. Tank 241-SY-102 has a transuranic (TRU) sludge in the bottom. Current rules prohibit mixing complexed waste with TRU waste. Tank 241-SY-103 has three major problems. First, tank 241-SY-103 is on the F7ammable Watch 7ist. Second, adding waste to tank 241-SY-103 has the potential for an episodic release of hydrogen gas. Third, tank 241-5Y-103 will not hold al7 of the potential7y complexed waste from the SSTs.

This document looks at more details regarding the salt well pumping of the 200 West Area tank farm. Some options are considered but it is beyond the scope of this document to provide an in-depth study necessary to provide a defensible solution to the complexed waste problem. 
WHC-SD-W236A-ES-015

REV. 0

\section{TABLE OF CONTENTS}

1.0 BACKGROUND $\ldots \ldots \ldots \ldots \ldots$

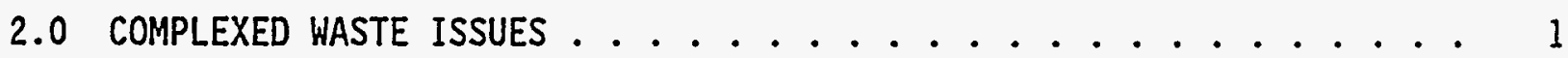

3.0 PROBLEMS ASSOCIATED WITH COMPLEXED WASTE . . . . . . . . . 2

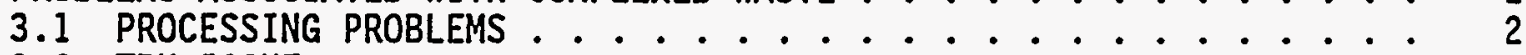

3.2 TRU ISSUE $\ldots \ldots \ldots \ldots$

3.3 PRETREATMENT ISSUE $\ldots \ldots \ldots . \ldots \ldots$

$4.0200 \mathrm{~W}$ AREA SEGREGATION ISSUES ................. 4

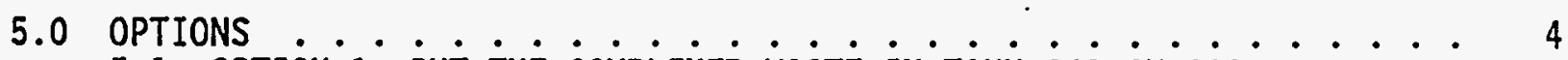

5.1 OPTION 1 PUT THE COMPLEXED WASTE IN TANK 241 -SY-103 . . . 4

5.1.1 Option 1A Mitigate Tank 241-SY-103 by Di.lution .... 8

5.2 OPTION 2 LEAVE THE COMPLEXED WASTE IN THE SINGLE-SHELL TANKS

(SST) . . . . . . . . . . . . 8

5.3 OPTION 3 TRANSFER THE COMPLEXED WASTE CROSS SITE FROM A DCRT . 9

5.4 OPTION 4 MIX THE COMPLEXED WASTE WITH THE TRU WASTE IN TANK

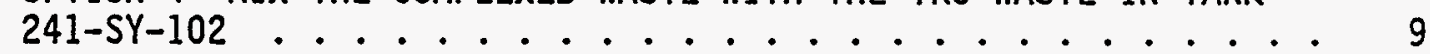

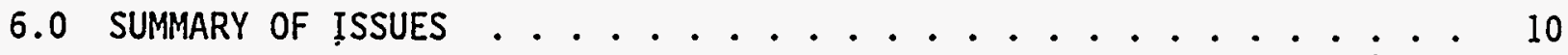

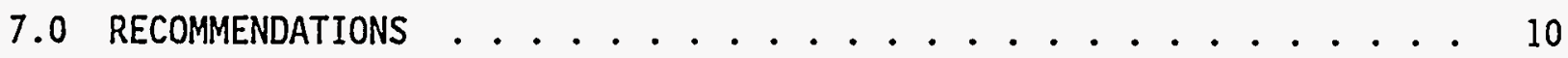

8.0 BIBLIOGRAPHY . . . . . . . . . . . . . . 11

APPENDIX

A OPTIONS FOR PUMPING COMPLEXED WASTE IN THE 200 WEST AREA . . . . . A-1 
WHC-SD-W236A-ES-015

REV.O

\section{LIST OF TERMS}

DCRT

DOE

DST

EDTA

HEDTA

PFP

SST

TOC

TRU double-contained receiving tank

U.S. Department of Energy

double-shell tank

ethylenediametetracetic acid

$\mathrm{N}$-hydroxyethy 1-ethylenediaminetriacetric acid

Plutonium Finishing Plant

single-shell tank

total organic carbon

transuranic (waste) 
WHC-SD-W236A-ES-015

REV. 0

WASTE SEGREGATION ANALYSIS FOR SALT WELL PUHPING IN THE 200 WEST AREA - TASK 3.4

\subsection{BACKGROUND .}

The Tri-Party Agreement requires completion of interim stabilization of single-she11 tanks (SST) by September 30, 2001. There are 34 tanks in the 200 West Area that require salt well pumping by that date. Some of this waste contains organic material in high enough quantities to be classed as complexed waste. The organic species are able to hold strontium and the transuranic elements in solution. In addition, organic species tend to increase the viscosity of the waste material.

Interim stabilization consists of pumping SST liquids to double-shell tanks (DST). This analysis is to determine if the 200 West Area SST liquids that are complexed can be pumped to the limited available DSTs. Two of the three DST in the 200 West Area 241-SY tank farm are on the Flammable Gas Watch List. These tanks are 241-SY-101 (101-SY) and 241-SY-103 (103-SY). Both of these tanks are classed as complexed waste by Hanlon (1994). The other tank, tank 241-SY-102 (102-SY), receives waste from the Plutonium Finishing Plant (PFP). The solids in tank 102-SY contain some of the highest concentrations of TRU in the DST tank farm. However, there is little or no organics in the waste and the liquid waste above the solids is classed as noncomplexed non-TRU waste.

\subsection{COMPLEXED WASTE ISSUES}

Complexed waste resulted from B Plant operations when organic complexants such as ethylenediametetracetic acid (EDTA), $\mathrm{N}$-hydroxyethylethylenediaminetriacetric acid (HEDTA), and giycolic acid were added to waste to help recover strontium-90. This occurred in the 1970s. These organic complexants formed organic ions in waste solutions.

At the time complexed waste was generated from B Plant in the 200 East Area, the 242-S evaporator in the 200 West Area was the only operating evaporator. Consequent7y, the waste was staged through several tanks in the 200 East and 200 West Areas and finally concentrated in the 242-S evaporator. Several tanks in the $200 \mathrm{~W}$ Area were used to store the complexed concentrate. When 241-SY tank farm became available, the complexed waste was transferred to $101-S Y$ and .103-SY.

In 1980, most of the complexed concentrate in 103-SY was diluted and sent to the 200 East Area. There the waste was reconcentrated and transferred to several tanks before being transferred to tanks 241-AN-107 (107-AN) and 241-AN-102 (102-AN). Because of the many transfers between the 200 East and 200 West Areas, there is potential for complexed waste to be in many tanks. 
Historically, the TRU waste, the complexed waste, and the noncomplexed waste have been segregated from each other. This procedure has been documented in several places but most notable in the various Waste Volume Projection documents. Complexed waste is defined as waste that contains total organic carbon (TOC) greater than $10 \mathrm{~g} / 1$ when concentrated in the evaporator up to the double-she11 slurry feed.

\subsection{PROBLEMS ASSOCIATED WITH COMPLEXED HASTE}

Complexed waste has been segregated from other waste since it was first generated and introduced into the waste tanks. Processing problems with the complexed waste were a primary concern in this document. Other concerns of complexed waste were dissolving TRU elements and the added cost of pretreatment. Each of these issues wi17 be discussed in this document.

\subsection{PROCESSING PROBLEMS}

Complexants have the potential to cause problems as the waste is concentrated in the evaporator. The organic complexant interferes with the crystallization process of the inorganic constituents e.g., $\mathrm{NaNO}_{3}$. Instead of supersaturation being relieved by growth of large crystals, complexed waste tends to supersaturate and then release a myriad of nucleus size crystals. These fine crystals cause a rapid build up in viscosity and do not settle.

Below are some excerpts from old laboratory letters that point out the difficulties with evaporating complexed waste. (The emphasis has been added.)

"Complexants such as EDTA and HEDTA in the waste inhibit the nucleation and growth of crystals in the evaporator-crystallizer. As a result, the waste solutions became supersaturated to the point that massive nucleation of extremely small crystals occur. When massive nucleation occurs, the concentrate becomes extremely thick and viscous with a consistency similar to Vaseline. Evaporating the waste at higher pressure raises the temperature of the evaporator. The higher temperatures prevent nucleation allowing further evaporation before massive nucleation occurs." (Robbins 1978)

"In an earlier letter, it was reported that hand cream slurries resulting from evaporation of complexed waste could be successfully converted to drainable salt cakes by high-temperature digestion." (Robbins 1980)

"(1) STurry turned gelatinous.

(2) Viscosity ranged from $15,000 \mathrm{cp}$ at high shear force and $50{ }^{\circ} \mathrm{C}$ to $400,000 \mathrm{cps}$ at $70 \mathrm{w}$ shear force and room temperature.

(3) Viscosity ranged from $18,000 \mathrm{cps}$ at high shear force and $50^{\circ} \mathrm{C}$ to $800,000 \mathrm{cps}$ at low shear force and room temperature." (Horton 1977) 
"The 4b-1 s7urry turned into a gel with the consistency of vaseline when left overnight in the oven at $65^{\circ} \mathrm{C} . "$ (Wright 1977)

Historically, complexed waste was only concentrated up to the point of saturation because of the tendency to become a gel beyond tht concentration. Some guidelines indicate that up to $5 \%$ solids are acceptable. other definitions say the waste can be concentrated up to the point that sodium nitrate starts to precipitate. In either case, it is not acceptable for this waste to turn into a "gel" in the waste tank or transfer line. For a point of reference, the supernate density of 107-AN is $1.39 \mathrm{~g} / 1$ and for 102-AN the supernate density is $1.40 \mathrm{~g} / 1$. These are both complexed concentrate tanks. The waste in these tanks initially contained little or no solids and the bulk of the waste was fluid.

When complexed waste and noncomplexed waste is mixed, the results are that the noncomplexed waste is evaporated less than it would be if mixing did not take place. Therefore, mixing these two types of waste could potentially cause a net loss of space in the tank farm by mixing complexed and noncomplexed waste.

\subsection{TRU ISSUE}

The complexants were used to complex di- and tri-valent cations in the $B$ Plant solvent extraction process. In tank. Wastes, the complexants keep these sparingly soluble ions in solution. The difficulty is that the TRU elements and strontium 90 are complexed and held in solution. There is a potential that TRU elements in a sludge in a tank can be redissolved in complexed waste (Delegard 1994). This would then allow the TRU to be spread to other tanks as the liquid waste is transferred. An additional concern is that complexants may allow the TRU to migrate through the soil column should the waste leak to the ground, although this is a minor concern for DSTs.

The present interpretation of U.S. Department of Energy (DOE) Order 5820.2A is that TRU waste is to be kept separate from other waste (see Section 5.4).

\subsection{PRETREATHENT ISSUE}

Final disposal $\mathrm{plans}$ for the waste in tanks is to produce high-level and low-level glass. The high-level glass will contain the TRU and long-lived radionuclides. The $10 \mathrm{w}-1$ evel glass will have rather stringent requirements for TRU, ${ }^{137} \mathrm{Cs}$, and ${ }^{90} \mathrm{Sr}$. The current $\mathrm{plan}$ to use a simple, low-cost in-tank washing process would be sufficient to separate the TRU waste from the remainder waste.

Complexed waste complicates the pretreatment process. The pretreatment of waste before vitrification requires a process that destroys the organic compounds and releases the TRU (Orme 1994). If complexed waste is not segregated but blended with other waste, there is a potential that more waste will have to go through the organic destruction process. This will increase 
REV. 0

final disposal, complexity, and costs. Unless evaluations of blending scenarios show it to be cost effective, it is prudent to continue segregation of complexed wastes.

\section{0 $200 \mathrm{~W}$ AREA SEGREGATION ISSUES}

The 200 West Area has only three DSTs. This 1 imits the options for storing the complexed waste that will be pumped from SSTs. The remainder of this document will explore what options are available to transfer the complexed SST Tiquid in the 200 West Area to DSTs.

Table 1 shows the current level of the three tanks in the 241-Sy tank farm. These tanks have an Operational Specifications Document limit of 422 inches. In the past, the waste in 101-SY has been above that limit. No-waste has been removed from the tank since that time. Adding more waste into 101-SY does not appear practical.

Table 1. Level in 241-SY Tank Farms. (Hanton 1994)

\begin{tabular}{|c|c|c|}
\hline Tank & Leve1, inches & Type of waste \\
\hline $241-S Y-101$ & 401.1 & Complexed Concentrate \\
\hline $241-S Y-102$ & 277.5 & Dilute Noncomplexed/PT \\
\hline $241-S Y-103$ & 272.0 & Complexed Concentrate \\
\hline
\end{tabular}

The volume of complexed waste yet to be pumped is not known at this time. It does appear that there is over one million gallons in the 200 West Area (see Appendix A). The total volume of SST liquids in the 200 West Area exceeds the available volume in the 241-SY tank farm; therefore, a17 options assume that noncomplexed Tiquids are pumped to 102-SY and cross-site to the 200 East Area.

\subsection{OPTIONS}

Four tank waste options were developed for this study. Sections 5.1 through 5.4 are an explanation of each option.

\subsection{OPTION 1 PUT THE COMPLEXED WASTE IN TANK 241-SY-103}

In the past, complexed waste from the 200 West Area SSTs was transferred to 103-SY. However, 103-SY is now on the Flammable Gas Watch List. This presents several difficulties in transferring complexed waste to 103-SY. Public Law 101-510 (the Hyden Bi71) states that waste cannot be added to tanks 
WHC-SD-W236A-ES-015

REV. 0

on the Watch List without approval from the Secretary of Energy. Several technical issues would need to be addressed if this option is pursued. These technical issues are explained below.

\section{Compatibility}

The compatibility of the wastes should be studied to ensure that the two wastes do not interact in a way that would compromise the safety of the tank. Sampling of 103-SY is current7y underway and results from the laboratory are not yet available. Information from the SSTs is not available. However, it appears that the waste compatibility criteria is favorable for mixing the complexed waste from SSTs with the waste in 103-SY. 'The density criterion, to prevent a tank from being placed on the Flammable Gas Watch List, may not be important for a tank that is a.7ready on the 1 ist.

\section{Flammable Gas Issues}

The basic question for the flammable gas issue is: If complexed waste were added to 103-SY, would that increase the safety problems with 103-SY? The answer to that question is probably -- YES. Samples of complexed wastes from SSTs indicate that they are at or near the saturation point. This means that the waste from SSTs cannot dissolve many solids in 103-SY. Adding those wastes to 103-SY would probably not help mitigate 103-SY by dilution.

Figure 1 shows the fill history of 103-SY. There were three major fills with a period of time in between the fills. Only the two fills after the double-shel1 slurry run of 1980 are shown in Figure 1 . The period of time after the fills will be considered later.

Figure 2 shows the time period after the end of the 1980 double-shell slurry run. During this time period, the tank contained about 80 inches of unpumpable complexed concentrate and the remainder was double-shell slurry. Notice that the surface level increased and decrease which is indicative of a waste that is trapping and releasing gas. However, the decreases are typically very slow and not very large.

Figure 3 shows the period after uranium recovery ion exchange fiush was put into the tank. This flush was fairly dilute. The surface level continued to fluctuate and the drops in surface level were slow and not very large.

Figure 4 shows the period of time after waste from SST 241-SX-104 (104-SX) was pumped to the tank. After a period of time, the ramp-then-sudden-drop sequence can be seen in the surface level. This sudden drop is the period of the cycle that causes the sudden increase in hydrogen in the head space of the tank. 
WHC-SD-W236A-ES-015

REV. 0

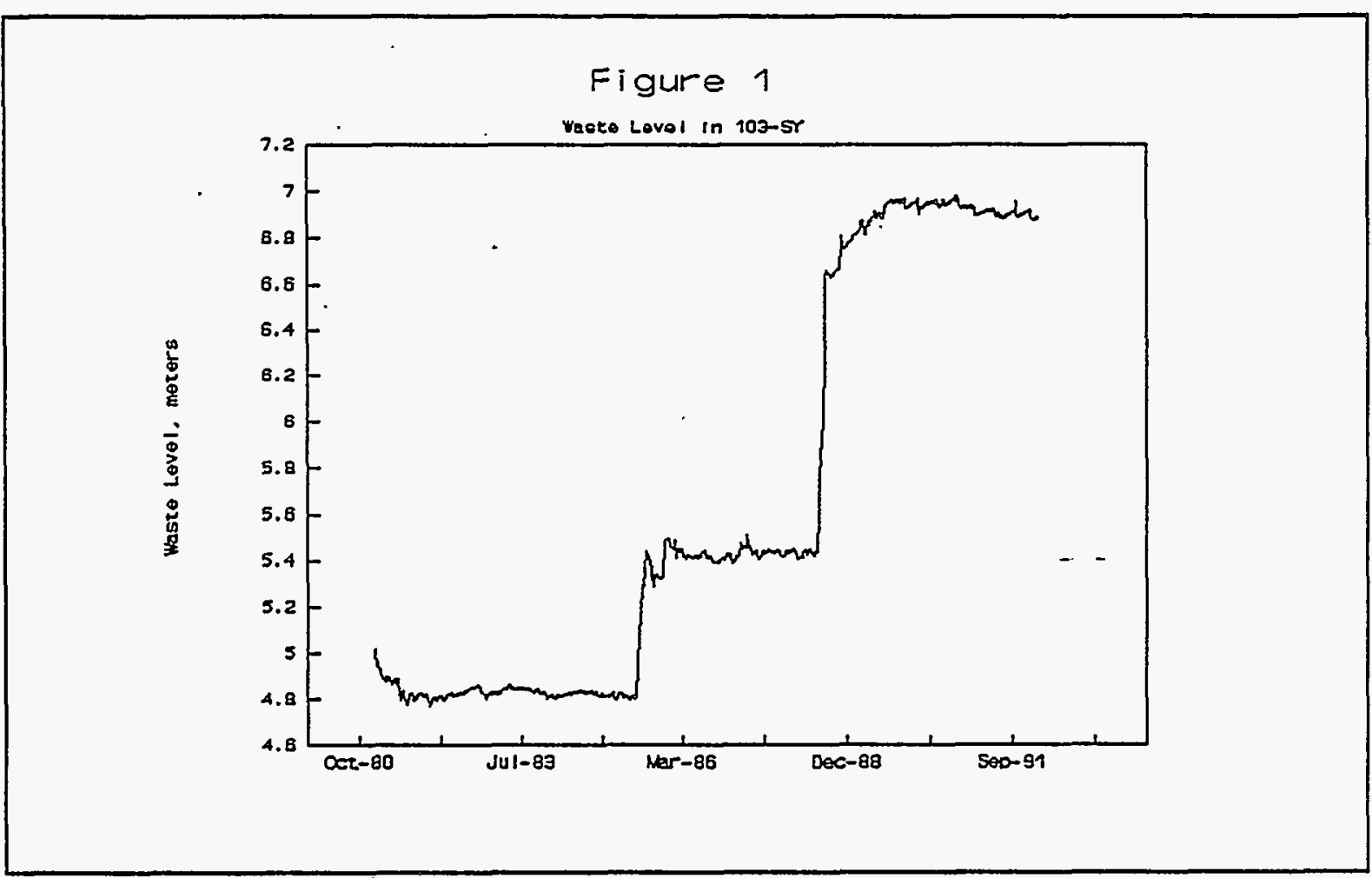

Figure 2

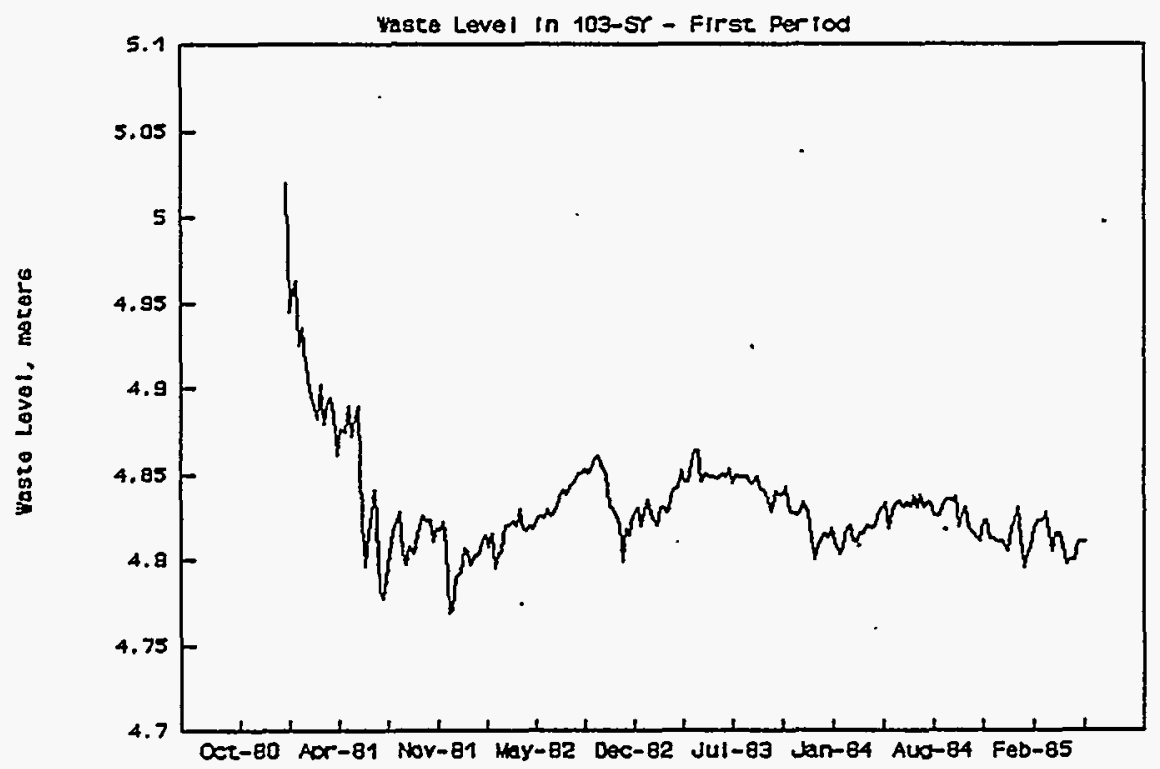


WHC-SD-W236A-ES-015

REV. 0

Figure 3

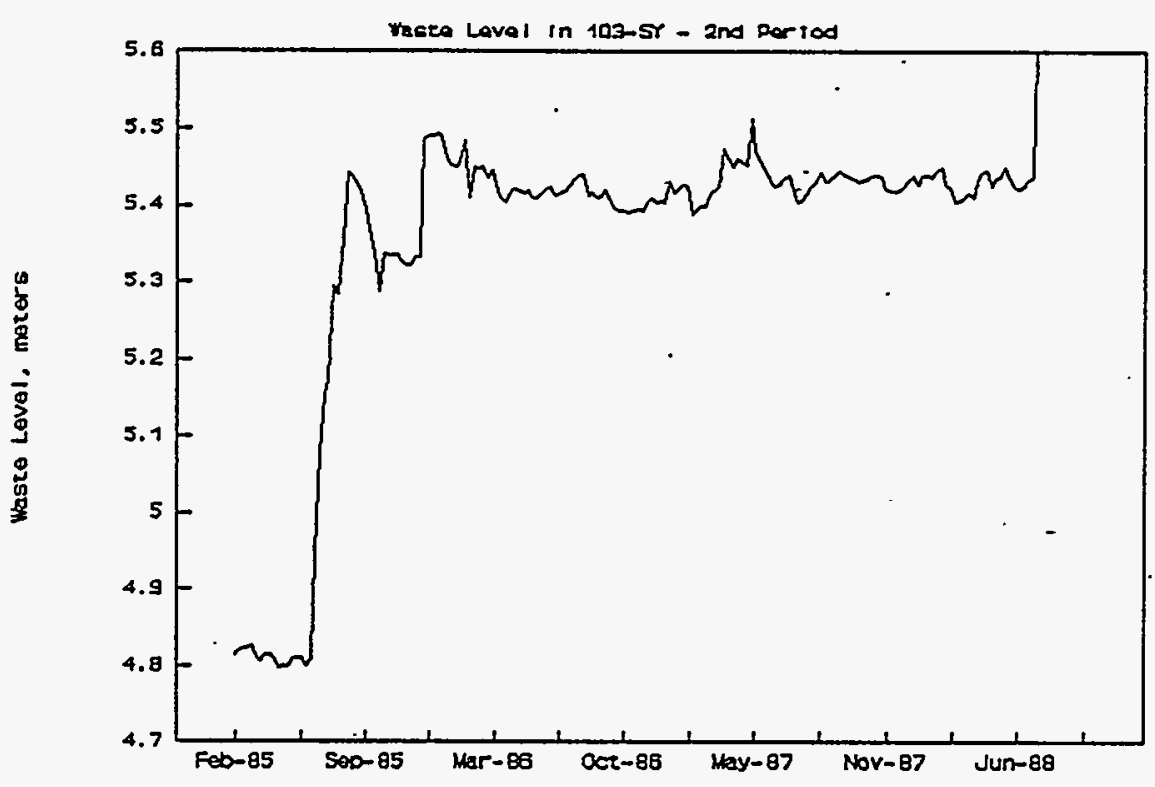

Figure 4

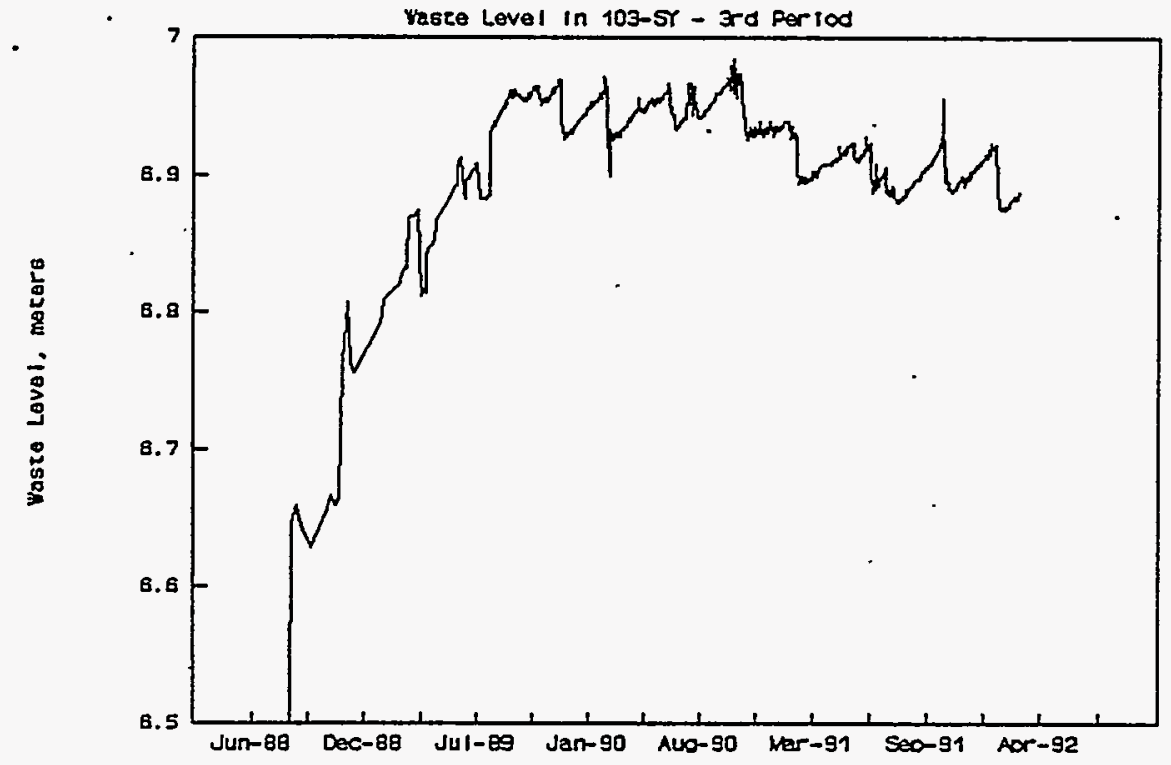


REV. 0

This sequence indicates that adding waste, including that from a SST, made the flammable gas problem worse in 103-SY. It is speculated that 103-SY started without enough fluid to allow the tank contents to roll over and, therefore, slow and nonvigrous gas releases resulted. The addition of more fluid wastes, such as from 104-SX, allowed the tank to roll over. Whatever the mechanism, the results of past waste additions do not indicate that it will improve the flammable gas behavior if complexed single-she17 liquid is put in 103-SY.

Another problem of adding additional waste to $103-5 Y$ is that such an addition will decrease headspace for dilution of hydrogen that is released. Currently, the headspace in $103-S Y$ is $2,500 \mathrm{~m}^{3}$. If waste additions bring the surface level up to $9.94 \mathrm{~m}$ (391 in), half of the headspace has been lost. Therefore, the dilution of hydrogen with air during a gas release will decrease.

As an example, in January 1992 there was a gas release event in 103-SY. This gas release event released $79 \mathrm{~m}^{3}$ of gas into the tank dome. Assuming an instantaneous release of gas that was 30\% hydrogen, then the tank headspace would have been $0.95 \%$. hydrogen. This is below $25 \%$ of the lower flammable 7 imit of hydrogen in air. Had there been $9.94 \mathrm{~m}$ of waste in the tank, the head space concentration would have reached $1.9 \%$ hydrogen. While this is still below the lower flammable 7 imit, $1.9 \%$ is above the 7 imit set for mitigation. Clearly the hydrogen concentration would be safer at the lower waste levels.

Another problem is that adding waste will increase the hydrostatic head on the gas stored in the waste. The added hydrostatic head compresses the bubbles, which would mean that more gas must accumulate before neutral buoyancy is reached. Neutral buoyancy is necessary for a roll over to occur. More gas would be released should a gas release event occur.

\subsubsection{Option 1A Mitigate Tank 241-SY-103 by Dilution}

If 103-SY were mitigated by dilution and transferred cross site, then 103-SY would be available for receiving the complexed waste from SSTs. Timing is a major concern here. The question is could 103-SY be diluted in time to meet the dead7ine for pumping the SSTs.

\subsection{OPTION 2 LEAVE THE COMPLEXED WASTE IN THE SINGLE-SHELL TANKS (SST)}

Leaving the complexed waste in the SSTs until a tank is ready to receive this waste into a DST is another option. If this option is used, the Tri Party Agreement milestone on stabilizing the SSTs would probably not be met. This option could compromise tank integrity. SSTs usually develop one leak per year. Another concern is that if complexed liquids leak from SSTs, normaliy insoluble radionuclides could be carried into the soil. The complexant typically holds the TRU in solution so that the TRU would migrate farther with the complexant than without. Leaving complexed waste in SSTs would put the worst waste at risk for release to the environment. 
WHC-SD-W236A-ES-015

REV. 0

\subsection{OPTION 3 TRANSFER THE COMPLEXED WASTE CROSS SITE FROM A DCRT}

Under this option, the waste from SSTs is pumped to a double-contained receiving tank (DCRT). The complexed waste could be segregated and pumped cross site from one of the DCRTs. The DCRTs contain a nominal $75 \mathrm{~m}^{3}(20,000$ gal). The pump, however, is not designed for cross site transfers.

The cross site transfer line is a nominal $7.6 \mathrm{~cm}$ ( 3 inch) diameter and 10,000 $\mathrm{m}$ ( 6 miles) long. The volume to fill the 7 ine is $44 \mathrm{~m}^{3}$ (11,000 gal.). A transfer of waste cross site from a DCRT would require a large ratio of flush waster. This would be a very inefficient way to transfer waste cross site.

\subsection{OPTION 4 MIX THE COMPLEXED WASTE WITH. THE TRU WASTE IN TANK 241-SY-102}

Tank 102-SY is the only DST that is not on a watch list and is, therefore, not subject to the Wyden Bi11. However, 102-SY was the receiver tank for waste from the Plutonium Finishing Plant. Therefore, the amount of TRU in this tank is more than any other DST. This TRU is in the form of a sludge layer. at the bottom of that tank.

Adding complexed waste to this tank will probably dissolve some of the TRU (Delegard 1994). The amount of waste needed to achieve this is unknown at the present time. It is likely that adding the complexed waste to 102-SY may require additional pretreatment of the waste before final disposal. The pretreatment flowsheet currently calls for a complexant destruction step. There is also a TRU limit for the low level glass (Orme).

Current requirements do not allow for mixing of complexed waste with noncomplexed waste or mixing complexed waste with TRU waste (Carothers 1991 , and Carothers 1994). It would not be possible to pump the complexed wastes in the 200 West Area without violating some of those requirements.

Complexed waste has always been separated from other wastes because of operating problems caused in the tank farms. Complexants interfere with the crystallization in the evaporator. Instead of rather large crystals, complexed waste forms a myriad of very fine crystals. These crystals increase the viscosity rapidiy. Laboratory reports typically compare complexed waste with "Vaseline" when complexed waste is concentrated to the period of crystallization. This rapid viscosity means that other waste mixed with complexed waste is less concentrated. With the potential of a tank shortage, it would be prudent not to mix complexed waste with other waste.

\section{Regulatory Requirements}

Current1y, DOE orders require that TRU wastes be segregated from other waste types. These DOE order requirements are stated below.

"This may include separation of high-level waste into other waste categories, such as transuranic waste or low-level waste (DOE 1988)." 


\begin{abstract}
"Any material that is known to be, or suspected of being contaminated with transuranium radionuclides shall be evaluated as soon as possible in the generating process, and determined to be either recoverable material, transuranic waste, low-level waste, mixed waste, or non-radioactive trash in order to avoid commingling the various material streams (DOE 1988)."

"To the extent practical, waste in DSTs shall be segreg!ted by HLW, TRU waste, and LLW types. Waste transfers shall be evaluated prior to execution to ensure compatibility of wastes" (DOE/RL 1993)
\end{abstract}

\title{
6.0 SUMMARY OF ISSUES
}

Complexed waste can produce slurries of "Vaseline" consistency. Complexed waste has been separated and concentrated only up to the point of sodium nitrate crystallization to prevent high viscosity material stored in tanks. The separation prevented contaminating other waste that could be further concentrated.

Complexed waste can bring TRU material into solution. This would mean additional pretreatment requirements and costs for final disposal.

It is not practical to add waste into 101-SY and 103-SY. There is probably more complexed waste stored in SSTs than could be stored in 103-SY.

Tank 102-SY has a sludge Tayer that contains TRU material. Adding complexed waste may bring some of the TRU material into solution. Tank 102-SY is the only 200 West Area DST that can be used to accumulate waste prior to cross site transfers.

\subsection{RECOMMENDATIONS}

There are a number of options for pumping complexed waste from the 200 West Area tanks. These include sluicing out 102-SY and transferring across site, leaving complexed waste in SSTs, and mixing the waste. A study to evaluate these options should be done soon to minimize the impact to TPA milestones.

A strategy for further study of the 200 West complexant problem has been outlined. The memo containing this strategy is attached as Appendix $A$. 


\subsection{BIBLIOGRAPHY}

Carothers, K. G., 1994, Data Quality Objectives for the Waste Compatibility Program, WHC-SD-WM-DQO-001, Westinghouse Hanford Company, Richland, Washington.

Carothers, K. G., 1991, Tank Farm Waste Compatibi7ity Program, WHC-SD-OCD-015, Westinghouse Hanford Company, Richland, Washington.

Delegard, C. H., "Solubilization of Strontium and Americium in Tank 102-SY", Internal memo to D. A. Reynolds, November 7, 1994, IM 8E110-PCL94-101, Westinghouse Company, Rich 7 and, Washington.

DOE, 1988, U.S. Department of Energy, Order 5820.2A, Radioactive Waste Management, Washington, D.C.

Forney, C. E., 1989, Single-She17 Tank Waste Pumping Strategy, WHC-SD-WM-TI-274, Rev. 1, Hestinghouse Hanford Company, Richland, Washington.

Hanlon, B. M., 1994, Tank Farm Surveillance and Waste Status Summary Report for May 1994, WHC-EP-0182-74, Westinghouse Hanford Company, Rich7and, Washington.

Herting, D. L., 1994, TRU Solubility Mixing Study for Tanks T-111 and 102-SY, Internal memo to M. J. Sutey, Apri1 4, 1994, IM 12110-PCL94-030, Apri1 4, 1994, Hestinghouse Hanford Company, Richland, Hashington.

Horton, J. E., 1980, "Process Aids, a compilation of Technical Letters," Vol. 12,

Orme, R. M., 1994, TWRS Process F7owsheet, WHC-SD-TI613, Rev. 0, Westinghouse Hanford Company, Richland, Washington.

DOE-RL, 1993, Radioactive Waste Management, U.S. Department of Energy, RLID 5820.2A, Richland Operations Office, Richland, Washington.

Robbins, J. K., 1978, "Process Aids, A Compilation of Technical Letters," Vo1. 10, RHO-CD-671, Rockwe11 Hanford Operations, Rich7 and, Washington.

Wilkins, N. E., 1994, Waste Behavior Analysis for Tanks 241-SY-103, WHC-SD-WM-TI-661, Westinghouse Hanford Company, Richland, Washington.

Wright, S. H., 1977, "Process Aids, A Compilation of Technical Letters," Vol. 9, Rockwe17 Hanford Operations, Richland, Washington. 
WHC-SD-W236A-ES-015

REV. 0

This page intentionally left blank. 
WHC-SD-W236A-ES-015 .

REV. 0

APPENDIX A

OPTIONS FOR PUMPING COMPLEXED WASTE IN THE 200 WEST AREA

A-1 
WHC-SD-W236A-ES-015

REV.0

This page intentionally left blank. 
From: $\quad$ Process Control

Phone: $\quad 373-3115$ R2-11

71330-95-001

Date: March 14, 1995

Subject: OPTIONS FOR PUMPING COMPLEXED WASTE IN 200 WEST AREA

To: A. M. Umek \$7-81

$\begin{array}{llll}\text { cc: C. W. Dunbar } & \text { R1-30 } & \text { T. E. Rainey } & \text { R2-54 } \\ \text { W. B. Barton } & \text { H5-27 } & \text { R. E. Raymond } & \text { R2-54 } \\ \text { D. B. Engelman } & \text { R1-49 } & \text { S. H. Rifaey } & \text { T4-07 } \\ \text { L. F. Ermold } & \text { S7-84 } & \text { J. P. Sloughter } & H 5-27 \\ \text { N. W. Kirch JWWK } & \text { R2-II } & \text { M. J. Sutey } & \text { T4-07 } \\ \text { J. M. Light } & \text { B4-08 } & \text { J. D. Thomson } & \text { R2-76 } \\ \text { D. M. Lucoff } & \text { R2-76 } & \text { DAR File/LB } & \end{array}$

References: (1) WHC-EP-0182-80, "Waste Tank Summary for Month Ending November 30, 1994," dated January 1995.

(2) WHC-SD-WM-TI-274, "Single-Shell Tank Waste Pumping Strategy," Rey. 1, dated October 4, 1989.

(3) Internal Memo, C. H. Delegard to D. A. Reynolds, "Solubilization of Strontium and Americium in Tank.102-SY," dated November 7, 1994:

This memo is to recommend a strategy for stabilization of 200 West Area single-shell tanks (SSTs) and identify the tasks to implement the strategy. The strategy consists of:

1) Identifying the SSTs that can be pumped without compatibility concerns (ie. non-complexed, nan-transuranic liquids).

2) Determining what additional information is required to evaluate the compatibility of complexed and/or transuranic liquids with designated receiver tanks.

3) Developing an emergency pumping plan and an interim stabilization plan for those SSTs with compatibility issues.

\section{BACKGROUND}

There is a Tri-Party Agreement Milestone to stabilize the single-shell tanks by September 30,2000 . Many of the single-shell tanks to be stabilized are in the 200 West Area. This presents some difficulties because the 200 West Area 
Page 2 of 6

March 14, 1995

has limited double-shell tank space; that is, only 3 double-shell tanks are located in 200 liest area and one is full.

There are currently 3.6 million gallons of pumpable single-shell tank waste in the 200 West Area (Reference 1). Preliminary findings of a recent evaluation may increase this volume to 4.4 million gallons. If the waste contained in Organic Watch List tanks is considered complexed, there are about 1.4 million gallons of complexed waste (i.e., about 40 percent of the waste may be complexed). Complexed waste was generated in the 1970 s from the B Plant strontium recovery process. Organic chelating agents (i.e., complexants) were added to the process to keep certain metals in solution. These complexants have the ability to hold transuranic elements, mainly americium, in the waste solution.

A strategy document for pumping the single-shell tanks was written in 1989 (Reference 2). This document did not take into account Public Law 101-510 (The Wyden Amendment) which limits the addition of waste to tanks which are on the Watch List. The Wyden Amendment prohibits the addition of waste to Watch List tanks unless a safer alternative cannot be found. The Secretary of Energy must approve the addition of waste to a Watch List tank.

Tank 241-SY-101 is, for all practical purposes, full. The current level is 402 inches but, with the waste that is presentiy in the tank, the level has been as high as 423 inches.

Tank 241-SY-103 is listed as containing 271 inches of complexed waste. An additional 400,000 gallons of complexed waste could theoretically be put into this tank, but it cannot hold all 1.4 million gallons that could be complexed. The main problem with 241-SY-103 is that it is a Flammable Gas Watch List tank. There is evidence that adding additional salt well liquor could make the flammable gas problem worse. In the past, $241-5 \gamma-103$ has shown some very slow increases and decreases in surface level. When additional waste was added to the tank (from single-shell tanks), the surface level decreases became rapid and appeared to give rise to more vigorous gas releases. A7so, adding more waste would not leave as much head space in the tank to dilute the gas. This has the potential of allowing flammable constituents in the tank vapor to reach concentrations of concern.

This leaves tank 241-SY-102 which has been receiving waste from the Plutonium Finishing Plant. It contains the greatest mass of transuranic (TRU) elements in the double-shell tank farm system. Currently, this TRU is in a sludge level at the bottom of the tank. If complexed waste is added to this tank, there is a strong possibility that some TRU will dissolve (Reference 3 ).

Historically, complexed waste and TRU wastes have been segregated for tank storage. The reason for this has been to minimize the amount of waste that requires more expensive disposal and to comply with DOE orders. DOE Order 5820.2a, "Radioactive Waste management," states. in Section I.3.b. (2) (e), "To the extent practical, waste shall be segregated by type (sludge, salt, high activity, and low activity) to make accessibility for future processing 
easier" and in Section II.3.e.(1), "Transuranic waste shall be segregated or otherwise clearly identified to avoid commingling of transuranic waste streams with high-level waste or low-level waste." Hanford has implemented this practice by segregating waste that was considered complexed (greater than 10 grams/liter total organic carbon) from TRU waste sludge.

One additional reason for segregating complexed waste has been processing problems in the evaporator. The organic complexants interfere with the crystallization process resulting in extremely thick, viscous slurries. When complexed and non-complexed wastes are mixed, the resulting mixture cannot be evaporated to as low a volume.

The bottom line is the complexed waste in 200 West Area single-shell tanks cannot be pumped for stabilization in time to meet the Tri-Party Agreement Milestone without violating existing rules.

\section{IDENTIFY TANKS WHICH CAN BE PUMPED}

The first part of the strategy for stabilization of the 200 West Area SSTs is to identify those tanks which are neither complexed nor TRU. These tanks are compatible with staging in 241-SY-102.

Table 1 presents a summary of availabie information on the non-stabilized 200 West Area SSTs. Tanks 241-S-101, -S-103, -S-106, -S-108, -S-109, 241-SX-101, 241-T-104, -T-107, and 241-U-111 are a 17 shaded because the available information indicates that these tanks are compatible with 241-SY-102. These nine tanks are estimated to contain up to $800 ; 000$ gallons of liquid for nearterm stabilization pumping.

Tanks 241-S-102, 241-SX-106, 241-U-106 and -U-107 are highlighted with a bold outline because these tanks are on the Organic Watch List. In addition, information on tanks 241-SX-102, -SX-104 and 241-U-102 indicate these tanks are complexed. There are approximately 1 million gallons associated with these seven tanks. The remaining eleven tanks, containing up to 2.6 million gallons, have no available analysis to show if the liquid is complexed. These tanks (plus some others with suspect analysis) require samples and analysis to determine compatibility with 241-SY-102. 
WHC-SD-H236A-ES-015

REV. 0

A. M. Umek

Page 4 of 6

$-71330-95-001$

March 14, 1995

Table 1

\begin{tabular}{|c|c|c|c|c|c|}
\hline \multicolumn{6}{|c|}{ Volumes and Concentrations of Single Shell Tanks } \\
\hline Tank & Liters & Gallons & $\begin{array}{l}\mathrm{TOC} \\
\mathrm{gm} / 1 \\
\end{array}$ & $\begin{array}{l}\text { TRU } \\
\text { nCi/g }\end{array}$ & $\begin{array}{l}\text { Need } \\
\text { Samole? }\end{array}$ \\
\hline$\% S>101 \% \%$ & 405,000 & 107,000 & $3.21(191)$ & & \\
\hline $5-102$ & $1,140,000$ & 301,000 & $13.79 \% \%$ & & YES \\
\hline $15 \div 103 \ldots$ & 409,000 & 108,000 & $4.32(\cdot 91)$ & 1.18 & \\
\hline \$\$ $106 \% \%$ & 636,000 & 168,000 & $1.5(\cdot 92)$ & .33 & \\
\hline$s-107$ & 280,000 & 74,000 & $3.8(: 91)$ & $1000 ?$ & \\
\hline \% $108 \%$ & 397,000 & 150,000 & $2.12(191)$ & .4 & \\
\hline \%: $: 109 \% \% \%$ & 450,000 & 199,000 & $1.24(191)^{\circ}$ & .15 & \\
\hline$s \cdot 110$ & 390,000 & 103,000 & & & YES \\
\hline$s-111$ & 507,000 & 134,000 & $6 .(178)$ & & YES \\
\hline$s-112$ & 405,000 & 107,000 & & & YES \\
\hline 6sx $101 \% \%$ & 189,000 & 50,000 & $0.32(190)^{\circ}$ & $\leq 110$ & \\
\hline $5 x-102$ & 988,000 & 261,000 & $32780 \times \%$ \% & & YES \\
\hline $5 x-103$ & $1,130,000$ & 298,000 & & & YES \\
\hline $5 x-104$ & 738,000 & 195,000 & $(45,0 \% 131 \%$ & $7 . E-05$ & \\
\hline $5 x-105$ & $1,340,000$ & 555,000 & & & YES \\
\hline $5 x-106$ & $1,2000,000$ & 317,000 & & & YES \\
\hline \%1840\% & 223,000 & 59,000 & $.541(194)$ & $<9.6$ & \\
\hline 16107: & 68,000 & 18,000 & $0.855(193)$ & 2.E-08 & \\
\hline$T-110$ & 178,000 & 47,000 & & & YES \\
\hline U. 102 & 636,000 & 168,000 & 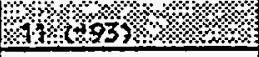 & 20 & $\cdot$ \\
\hline$U-103$ & 886,000 & 234,000 & & & YES \\
\hline$U-105$ & 795,000 & 290,000 & & & YES \\
\hline$U-106$ & 310,000 & 82,000 & $38,1 \% 4 \%$ & 197 & \\
\hline$U-107$ & 617,000 & 163,000 & & & YES \\
\hline$U-108$ & 908,000 & 240,000 & & & YES \\
\hline U-109 & 844,000 & 223,000 & & & YES \\
\hline 2.1.1\% $2 \%$ & 541,000 & 143,000 & $6.15(193)$ & -5 & \\
\hline
\end{tabular}


A. M. Umek

Page 5 of 6

March 14,1995

ADDITIONAL INFORMATION NEEDS

Additional information is needed to develop a strategy for dealing with the remaining SST liquid in 200 West Area. The needed additional information is to address two main issues:

- Determination of SSTs that contain complexed waste.

- Evaluation of. impacts from pumping complexed SST liquid.

As stated previously, eleven of the remaining SSTs for interim stabilization in 200 West Area have little or no information to determine if the liquids are complexed. These tanks, plus others that have old or suspect analysis, should be sampled and analyzed for total organic carbon and TRU element concentrations.

Any tanks determined to be complexed should be evaluated to determine if the liquid exhibits complexant behavior. This means the liquid should be evaluated for dissolution of TRU from 241-SY-102 solids. Additionally, a laboratory boildown may be desired to determine if detrimental crystal behavior and high viscosity result from evaporation. This behavior can be evaluated with and without mixing with non-complexed waste to evaluate if waste volume impacts are associated with blending these streams.

PUMPING PLAN FOR 200 HEST AREA

A number of options exist for pumping 200 West Area SSTs. The following is a list of potential options that can be considered for either emergency pumping or interim stabilization. Combinations of these options can also be considered. As more information is gained on the SST Tiquid, these and possible other alternatives will need to be evaluated.

Pump the Non-Complexed Waste First As long as there is not a leak in a tank containing complexed waste, pumping all of the noncomplexed waste first and then the complexed waste could be possible. This would keep the two waste types segregated. The two main issues would then be the uptake of TRU with the complexed waste and what to do if a complexed waste tank starts to leak.

If a tank containing complexed waste starts to leak, then this tank could be pumped and the portion of noncomplexed waste in 241-SY-102 would be contaminated with complexants. This batch would probably have to be segregated but that could be an acceptable risk. The risk may be acceptable because, safety is not jeopardized. However, increased tank storage space. management, pretreatment costs and retrieval issues may result.

Mix Complexed and Non-Complexed Another option is to mix complexed and noncomplexed liquids and accept the consequences. The actual impact to waste volume has not been evaluated under the new evaporation limits. At the lower specific gravity values $(1.35-1.4)$, the impact on volume reduction may be low. There are also impacts for disposal associated with the total organic carbon and TRU levels that will require evaluation.

Retrieval of a Double-Shell Tank Additional space could be made available for segregation of complexed waste by retrieval and cross-site transfer of a 200 West Area double-shel1 tank. The TRU waste sludge in 241-SY-102 could be retrieved and transferred cross-site. It would resolve issues regarding 
A. M. Umek

Page 6 of 6

$71330-95-001$

March 14, 1995

commingling complexed and TRU waste, but the issues with mixing complexed and non-complexed waste would remain. Potential transfer line plugging would require resolution for this option.

Tank 241-SY-103 could also be retrieved, however dilution for retrieval without reconcentration would create tank space impacts.

Cross Site Transfer from a DCRT A double-contained receiver tank (DCRT) has a nominal volume of 20,000 gallons $(76,000)$ liters. The cross site transfer line hold a nominal 10,000 gallons (38,000 liters). A relatively large amount of flush water would be required.to transfer the waste but that could be removed at the evaporator in 200 East Area. The new cross site system will provide the pump to move clear across site. Flush drainage would al so have to be considered.

Truck the Complexed Waste Currently the 222-S laboratories are trucking the ir wastes to the 204-AR facility. It may be possible to truck the complexed waste also. That depends, however, on the dose rate and the loading facility.

Reactivate a Single-She 17 Tank If there were another tank in West Area, segregation of complexed and noncomplexed would be easier. A sound singleshell tank could be used. One possible candidate would be 102-S. This tank was used as an evaporator feed/dump tank. This tank could be used to accumulate waste until it could be pumped cross site.

Destroy the Complexant in West Area The organic complexant can be destroyed by heat and aggressive oxidation. There has been quite a bit of work done on methods to destroy the complexant. Perhaps activating the 242-S evaporator as a reaction vessel would be possible. The evaporator would hold about one DCRT and could heat the material. An oxidant such as peroxide could be added through the AMU system. While this may be slow, a significant amount of waste could be treated in a few years. This would also simplify pretreatment later on.

\section{CONCLUSION}

It is recommended that some of the tasks to address the complexed waste issue for 200 West Area be initiated immediately. The liquid sampling for those

- SSTs without composition information should be added to the sample schedule. The sample volume will need to be adequate to support additional lab work to assess the waste behavior if required. Also, the assessment of alternatives for emergency pumping can be initiated.

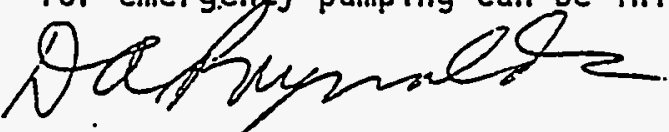

D. A. Reynolds, Fellow Engineer Process Controi

mjg 